\title{
The Relationship between School Administrators' Leadership Traits and Learning Schools: A Meta-Analysis Study
}

\author{
Muslim ALANOGLU \\ Turkish National Police, Mersin, Turkey \\ ORCID: 0000-0003-1828-4593 \\ Songul KARABATAK \\ Faculty of Education, Firat University, Elazig, Turkey \\ ORCID: 0000-0002-1303-2429
}

Article history

Received:

01.09 .2021

Received in revised form: 10.12.2021

Accepted:

20.12.2021

Keywords:

school administrator; transformational leadership; learning school; meta-analysis
School administrators' leadership characteristics are crucial in creating a learning school. Therefore, this study aimed to examine the relationship between transformational leadership characteristics and the learning school using meta-analysis. For this purpose, individual studies suitable for inclusion criteria were determined. In this context, we examined the studies between the years 2000 and 2020 on the relationship between school administrators' transformational leadership characteristics and learning schools. Studies including correlation coefficient, $t$ value, and sample size were covered to calculate the effect size required for metaanalysis. A total of 20 effect sizes were included in the 19 studies. In the study, analyses of forest plots, publication bias, heterogeneity, and subgroup tests were performed. The random-effects model conducted in the study determined that the overall effect size was positive and strong. The subgroup analysis showed that the country variable was the source of heterogeneity in effect sizes, while the publication type was not. The study revealed that leadership characteristics are significant predictors of learning school and one of the most critical leadership styles to create a learning school is transformational leadership. Policymakers and practitioners have essential duties in transforming schools into learning schools. Therefore, school administrators who want to turn their schools into learning organizations should always be supported by those who produce education policies.

\section{Introduction}

Education has an important place in the progress and development of societies. Schools, where education is carried out formally, are considered the most important educational institutions in the social context. As a fundamental education institution, the responsibility of schools is to provide individuals with the knowledge, skills, and values necessary to prepare them for the future as active members of society. For this reason, schools

\footnotetext{
*Correspondency: muslimalanoglu@gmail.com
} 
should transform into learning organizations to adapt to the constantly changing world (Ababneh, 2009). The learning capacity of schools is related to realizing their goals and their survival, and this capacity is associated with a large number of organizational outputs (Bil, 2018; Galimaka, 2012; Rashid \& Mansor, 2018; Srimulyani \& Hutajulu, 2013; Alanoglu, 2014). Although today's schools are expected to equip students with the knowledge and skills they will need to succeed in an uncertain and ever-changing future, many schools and teachers seem unable to develop the practices required to meet the needs of twenty-firstcentury students (Organization for Economic Development and Cooperation [OECD], 2016). Schools can provide students with the knowledge and skills by keeping their continuous learning mechanisms active. This situation necessitates the transformation of schools into learning organizations. Each student's learning style is different also reveals the necessity for schools to be learning organizations (Middlewood, Parker, \& Beer, 2005).

The need to adapt makes it inevitable for schools to change to be effective (Kursunoglu \& Tanriogen, 2009). Considering that the administrators will initiate the change in schools, administrators should use various leadership styles to facilitate this change (ChanLin, Hong, Horng, Chang, \& Chu, 2006). Other leadership styles, except transformational leadership, bring only short-term solutions to change. Nevertheless, since change and transformation create the basis of transformational leadership, transformational leaders ensure the transition and development of the school in every aspect by providing their continuous development (Celep, 2004).

School leaders who understand the potential benefits of organizational learning processes are likely to create a shared vision and continually motivate employees to improve themselves. School administrators play an essential role in designing learning and teaching processes at school by influencing teacher beliefs, behaviors, and practices (Bellibas, Polatcan, \& Kilinc, 2020). The research revealed that leadership has essential effects on increasing the quality of teaching in schools by affecting teachers' job satisfaction and cooperation levels, also show that school leadership affects school outcomes (Bellibas, Gumus, \& Liu, 2020).

The responsibility of the administrators is not only to provide qualified personnel for the organizations but also to take the necessary precautions and make arrangements for the continuous development of this personnel on the job. It may take a long time for schools to observe the effects of the measures taken and the regulations made because the output of schools is well-educated people. In this respect, the work of school administrators is a little more complex and essential, and it is possible to overcome this difficulty by transforming schools into learning schools. However, administrators who do not learn cannot understand, and administrators with transformational leadership characteristics are more open to learning because these leaders focus on learning, teaching, and transforming the organization (Toremen, 2001). This research is considered vital because it synthesizes the studies in the literature to reveal the role of transformational leadership in creating a learning organization and will make a foresight about the role of transformational leadership in creating a learning school. School administrators, who are a dynamic pillar of learning schools, are expected to move away from traditional management roles, also have modern leadership skills, and transform their schools into organizations that produce, transfer and use the information to fulfill their roles and responsibilities (Erturk \& Sezgin-Nartgun, 2019). For this reason, to determine the effect of school administrators on creating learning organizations, this study aimed to investigate the relationship between the transformational leadership characteristics of school administrators and the learning school. The impact of learning capacities on school outcomes and the role of school administrators in creating a learning school make it essential 
to determine the transformational leadership characteristics of school administrators and the learning school relationship. In addition, it is expected to provide crucial clues in terms of attracting the attention of policymakers about how meaningful the relationship of transformational leadership characteristics with the learning school is in the training of school administrators. Studies were synthesized by the meta-analysis method to reveal the relationship in question. The advantage of synthesis research is that it combines and explains inconsistent results in the literature (Ustun, 2012). Since transformational leadership characteristics could be critical in transforming schools into learning organizations, it was essential to synthesize the relationship between this leadership feature and the learning school with meta-analysis. We sought answers to the following questions to achieve the aim of the study:

(1) What is the effect size of the relationship between teachers' perceptions of learning schools and administrators' transformational leadership characteristics?

(2) How is the relationship between teachers' perceptions of learning schools and administrators' transformational leadership characteristics moderated by the countries studied and publication type?

\section{Conceptual Framework}

The conceptual framework of this study is built on transformational leadership's transformation of the school system into learning schools. School success depends on school leadership (Jacobson, 2011). School administrators are responsible for what teachers teach and students learn (Sergiovanni, 2001) causes attention to focus on the relationship between school leadership and learning school. School leadership, which can significantly affect organizational conditions, teacher behaviors, and students' learning outcomes (Hallinger, Piyaman, \& Viseshsiri, 2017), influences student learning and creates a quality school vision. That leads to organizational learning processes where teachers share their learning with others and improve their good teaching skills. It is a necessary element for education (Hallinger, 2003). Revealing such a vision, which is needed to transform schools into learning organizations, is related to the transformational leadership characteristics of the school administrator (Dexter, 2008; Korkmaz, 2008; Mulford \& Silins, 2003; Senge, CambronMcCabe, Lucas, Smith, Dutton, \& Klein, 2012). For this reason, transformational leadership is a crucial concept in learning schools. Because in learning schools, leaders always walk forward, regardless of their position in management or their hierarchical authority, and these leaders are transformational (Korkmaz, 2008). For this reason, empirical studies investigating the relationship between the transformational leadership characteristics of school administrators and the learning school formed the focus of this research.

\section{Literature Review}

The concepts of organizational learning, learning school, leadership, transformational leadership, and school administrators' leadership are examined in this section to understand the theoretical background of the research.

\section{Organizational Learning}

Contrary to the idea that systems emerged as a result of chaos, scientists who advocated the concept of living systems (e.g., Capra, 1996; Senge, 1990) argued that systems should be seen as complex fabrics that are constantly changing, interrelated, and interacting (Clarke, 2000). The need for constant movement and change necessitates the recognition of 
innovations and organizational learning because organizational learning is a dynamic process that enables the organization to adapt to changes (Hosseini, Hajipour, Kaffashpoor, \& Darikandeh, 2020).

Argyris and Schon (1978), one of the first researchers of organizational learning, stated that organizations learn during individual activities. Researchers considered organizational learning to identify, uncover, and correct errors. Organizational learning was defined by Stata (1989) as a process that takes place through shared understandings, knowledge and mental models, and past knowledge and experiences existing in organizational memory. Attitudes, practices, and strategies regarding organizational learning positively affect long-term performance outcomes (Garcia-Morales, Lopez-Martin, \& Llamas-Sánchez, 2006). Organizations become learning organizations as a result of organizational learning. A learning organization is defined as renewing itself (Senge, 2011), constantly learning, and transforming (Marsick \& Watkins, 1997). Organizational characteristics will emerge from effective leadership. These include mission and vision clarity, shared leadership and participation, encouraging organizational culture (Goh, 1998), and participatory decision making (Pedler, Burgoyn, \& Boydell, 1991) are needed to create a learning organization. In addition, an organic and flexible organizational structure is also required (Fiol \& Lyles, 1985).

Senge (2011) explains that the learning organization should have personal mastery, mental models, shared vision, and team learning characteristics. These features are not sufficient on their own and should be considered within the framework of system thinking. Of these characteristics, personal mastery is regarded as a process, not a goal or a solid-state. Personal mastery refers to the process of living and working towards a vision in line with one's values, in a state of continuous learning about themselves and the reality they are in (Bryant, 2020). Senge (2011) defines mental models as assumptions, generalizations, pictures, and images deeply rooted in our minds, and these models can affect how we understand the world and our actions. Organizational actions are also decided, shared, and put into practice through mental models. Therefore, the mental models of the decision-makers of the organization are significant. Shared vision is a development tool for organizational learning. The shared vision is a clear and familiar picture of a desired future state that members of an organization identify with themselves. It is an essential factor influencing knowledge acquisition and knowledge dissemination activities (Hoe, 2007). Team learning; touching on the importance of team members setting aside assumptions and establishing a dialogue to think together for real learning, Senge (2011) states that organizations cannot learn without team learning in today's organizations. Although organizations learn due to individuals learning, learning organizations emerge due to team learning. Systems thinking, defined as the fifth discipline by Senge, is the discipline needed to develop the other four disciplines. The discipline takes the other learning organization disciplines together and holds them together based on a coherent theory (Caldwell, 2012).

Apart from the five basic principles of organizational learning, there are also three essential elements. These are guiding ideas, innovations in the infrastructure, theories, tools, and methods. The crucial of these elements is to offer guiding ideas that school leaders can develop to get people to act together. It is also essential to redesign educational environments, educators, and available facilities to enable better learning. However, accomplished leaders can regulate some patterns and dynamics, research to take ideas further, and use different theories, tools, and methods (Senge et al., 2012). 
Studies on organizational learning have generally focused on businesses. On the other hand, the theoretical framework on organizational learning and approaches inspired by and adapted from business theories are used in educational organizations. However, when it comes to knowledge and learning, the first thing that comes to mind is school. While the school should be at the center of the concept of organizational learning, its relationship with organizational learning is established at the level of the second link (Collinson \& Cook, 2016). Especially after the emergence of school development models and total quality management approaches, the learning organization and organizational learning concepts have started to gain importance. While the concept of organizational learning defines the learning process, the learning organization defines the structure (Malhotra, 1996).

School administrators have the most active role in organizational learning in schools. School administrators ensure that individual learning is spread throughout the school in the organizational learning process. For this, they take the initiative to share the learned information with the group, interpret it together, and create a group understanding (Kocel, 2005). They involve not only teachers but also students and other staff in this process. Thus, school administrators transform schools into learning organizations.

\section{Learning school}

Schools are modeled in a structure that adopts hierarchical, sequential, linear, and technical learning approaches that promote teaching, efficiency, and excellence, but will inevitably fail when faced with a new paradigm (Clarke, 2000). It is possible to say that schools will turn into a practical structure by increasing their capacity to adapt to change through learning from this structure that prevents them from being successful. Schools need to transform into a learning system to improve their learning capacities. As a learning organization, the school has a shared vision that acts as a motivating force to achieve individual and school goals, and this shared vision is not a starting point but the result of a process involving teachers, students, parents, and other stakeholders (Middlewood et al., 2005).

Schools become learning organizations by developing a vision focused on the learning of all students, creating opportunities for continuous learning, promoting team learning and collaboration, creating a culture of discovery, learning with and from the external environment and the more extensive learning system, and modeling and nurturing learning leadership (OECD, 2016). In a school that focuses on learning; it is believed that learning is a lifelong process, that success will be achieved as a result of effort, that everyone in the school can learn and develop, and that families should be included in teamwork and school processes (Middlewood et al., 2005). The school increases its capacity to adapt to new environments and conditions as its members learn, individually and together, to realize their vision. The managers create the vision, motivation, and organizational structures for the learning organization and develop the organization (Senge, 2011). Leadership that reinforces learning is required for this development (Garvin, Edmondson, \& Gino, 2008). In other words, although the leader and other stakeholders have responsibilities in the learning school, it would be appropriate to say that the leadership of the school administrator plays a vital role in creating a learning school. Because in the leadership of learning schools, it is possible to go beyond "the school administrator does the right thing" (Senge, 2014). 


\section{Leadership and transformational leadership}

Leadership is a concept that has been emphasized for many years, and the success of individuals and organizations today largely depends on the success of the leaders. Therefore, the need for influential leaders and the discussions about leadership is increasing day by day (Bolden, 2004). Although it is a concept that has been extensively researched, defining leadership is not easy. Bennis (1989) states that leadership is like beauty, it is difficult to explain, but it can be recognized when seen. Turan (2020) says that there are nearly 350 definitions of leadership in the literature, and each of these definitions emphasizes a different feature of leadership. Yukl (2010), one of the pioneers of leadership research, defines leadership as a process of social influence. Similarly, Kruse (2013) states that although it is attributed to the top manager in the organization, leadership is a process of social power that maximizes the efforts of others towards achieving a goal. Definitions are made in different ways, but in almost all definitions, that leadership includes impact.

On the other hand, leadership involves reaching the goal and needs followers (Lunenburg \& Ornstein, 2013). According to Turan (2020), influence is related to the essence of leadership, the context of group leadership, objectives are related to the direction of leadership, and followers are associated with the existence of leadership. This definition draws a basic framework for leadership.

In the learning organization, the leader provides opportunities for employees to express their ideas and demonstrate their skills in developing collective mental models (Celik, 2012). The leader aims not to create a learning organization but to support individuals in how they will cooperate as they learn (Senge et al., 2012). The leader initiates actions to achieve learning goals, creates an equitable environment for all, and is confident that mistakes are a natural part of the learning process (Goh \& Ryan, 2002). Realizing such practices is related to the leadership styles exhibited in the organization. The potential of leadership styles shown by managers to provide innovation in the organization has caused studies on leadership to focus primarily on leadership styles (Chen \& Li, 2013). Leadership style can reflect the leader's management philosophy, worldview, and personality. The leaders' attitude towards their role and employees' role stands out as the main factor determining the leadership style (Denison \& Mishra, 1995).

As a leadership style, transformational leadership requires a separate effort in making and implementing joint decisions, especially with its employees. Transformational school leaders significantly increase teachers' commitment to the organization by enabling them to participate in various decisions (Leithwood, 1994) and delegate authority to students and teachers when necessary to create a shared culture at school (Jason, 2000). Therefore, transformational leadership skills are essential in creating learning organizations. Because transformational leaders build, manage, motivate, and support teams for organizational learning. Besides, transformational leaders encourage followers mentally, provide inspirational motivation and support them with self-confidence behaviors (Popper \& Lipshitz, 2000).

Transformational leadership focuses on some leadership behaviors that increase the motivation and performance of employees (Leithwood \& Jantzi, 2006). Transformational leadership is leadership where the leader and followers help each other reach a higher level of morale and motivation (Burns, 1978). Transformational leaders are also more successful than other leaders in motivating and empowering employees (Susan \& Whiteley, 2007). Transformational leadership is considered the most active and effective leadership style that 
encourages followers to perform beyond their official duties (Rubin, Munz, \& Brommer, 2005). This leadership style plays an essential role in school development and educational change (Leithwood \& Sleegers, 2006). There is a very high relationship between transformational leadership, organizational learning mechanisms, and organizational values (Lipshitz, Popper, \& Friedman, 2002).

\section{School administrators' leadership}

Effective and leading school administrators are likely to be more effective when they take a critical view of their schools' policies, practices, and procedures and develop a deep understanding of the cultures, norms, values, and expectations of students' families (Leithwood, 2021). However, the ever-increasing speed of technological development requires schools to change and develop. Moreover, school administrators are the most superior force that triggers change and reform. For this reason, it is expected that administrators in twenty-first-century schools have the expertise and will to recognize, develop and promote effective learning, encouraging teachers to improve their learning (Middlewood et al., 2005). The central role of school administrators can be to remove the obstacles to organizational learning by supporting or developing the learning needed (Middlewood et al., 2005). School leaders have essential effects on increasing the learning capacity of schools (Louis, Dretzke, \& Wahlstrom, 2010) because school leadership can affect the teaching practices of teachers inside and outside the classroom to improve student learning. An effective school leader can direct teachers' emotions and tendencies by influencing teachers' self-efficacy, collective competence, commitment, and confidence (Leithwood, Sun, \& Pollock, 2017; Singh, 2018). School leadership also matters an excellent deal to students' learning, and its contributions to such learning are primarily indirect (Leithwood, Sun, \& Schumacker, 2020), and it is assumed that influential school leaders effectively set vision and goals to increase student learning (Hallinger, 2011). Everyone has a role to play, not just school administrators, to realize changes that improve personal and collective activity. Therefore, it is believed that in learning schools, the leader and other stakeholders are responsible (Clarke, 2000). In this sense, it can be crucial for the leaders in the learning school to determine the roles and responsibilities, share the authority, and make the schools renew, develop, and transform themselves.

\section{Method}

This section explained the research model, data collection and inclusion criteria, data coding, and analysis.

\section{Research Model}

This study aimed to synthesize the results of empirical studies examining the relationship between the transformational leadership characteristics of school administrators and learning schools. For this reason, we used the meta-analysis method in the present study. The meta-analysis can be defined as the classification of research on a determined subject within the framework of specific criteria, comparing and combining the quantitative findings of these studies with statistical methods and obtaining a general result as a result of calculating the effect sizes (Cohen, Manion, \& Morrison, 2011; Dincer, 2014). The effect size is the value that shows the size of the relationship between the variables and is also the basic unit used in the meta-analysis with different methods (Sen, 2019). 


\section{Databases and inclusion criteria}

The study data was gathered in January 2021. Within the scope of the research, searched in ScienceDirect, Scopus, The Council of Higher Education Thesis Center, and Proquest databases as well as ERIC, EBSCOhost, ULAKBIM TR, and Google Academic indexes by using the key terms "transformational leadership", "organizational learning", "learning organization" and "learning school" in Turkish and English. As a result of the search, 867 studies were found, including transformational leadership characteristics and learning schools in educational institutions. The number of studies examining the relationship between both variables was found to be 87 . Thirty-one of these studies are postgraduate thesis, 47 are articles, and nine are conference papers. It was observed that some of the articles $(n=3)$ in question were derived from postgraduate theses, and these articles were not taken into account. The other 84 studies were examined considering the following criteria, and studies that did not meet these criteria were excluded from the scope of the study. The criteria considered in the study are presented, respectively.

(1) Studies should be published from the beginning of 2000 to 2020.

(2) Studies should be postgraduate theses written in Turkish or English, full-text conference proceedings, or scientific articles published in peer-reviewed journals [Some studies $(n=8)$ were omitted].

(3) Studies should be empirical, produce quantitative data, and include comparable statistics on the relationships between transformational leadership and learning school [Some studies $(n=24)$ were omitted].

(4) Studies should include the overall correlation coefficient or t values of the transformational leadership and the learning organization scales [Some studies $(n=5)$ were omitted].

(5) Studies should be conducted with the teachers and school administrators [Some studies $(n=16)$ were omitted].

(6) Validity and reliability information about the instruments used in studies should be given [Some studies $(\mathrm{n}=2)$ were omitted].

(7) The research should have presented statistical information to calculate the effect size [Some studies $(n=6)$ were omitted].

(8) The sample numbers in which the research was conducted should be given (It was seen that the sample numbers were assigned in all studies).

After the determined studies were examined according to the inclusion criteria, 19 studies were suitable for the desired criteria. In Aydın's (2012) study, separate analyzes were made for private and public teachers, and different data was collected for each sample group. For this reason, the study was evaluated as two separate studies, and a total of 20 effect sizes were included in the current study.

Besides, after the researchers coded the individual studies included in the meta-analysis, two more researchers were included in the study to ensure the consistency of the data. These researchers were asked to enter the necessary data in the columns of the variables created in the data file (name of publication, year of publication, country of study, correlation coefficient, sample size, etc.).

\section{Coding}

After the studies included in the research were determined, the data coding phase was started. We developed the coding form (ANNEX-1) for the study. The coding form consisted 
of the identity of the study (authors, year, title, type of publication, scale, and country), the variables of the study, and the data of the study $(N, t, r, p$, and $S D)$. The mentioned information was transferred to the form created separately by the researchers. Then these forms were compared, and the final form was created. In line with the information obtained from the coding form, the moderator variables of the study were determined as the country where the study was conducted and the type of publication. The descriptive data reached in the study are presented in Table 1.

Table 1. Descriptive data reached in the study

\begin{tabular}{lll}
\hline Subgroups & & f \\
\hline & Turkey & 6 \\
& Malaysia & 4 \\
Iran & 2 \\
Country & USA & 2 \\
& Israel & 1 \\
& Indonesia & 1 \\
& Taiwan & 1 \\
& Thailand & 1 \\
& Bangladesh & 1 \\
& Greece & 1 \\
\multirow{5}{*}{ Publication Type } & Article & 11 \\
& Doctoral Dissertation & 3 \\
& Conference Paper & 3 \\
\hline
\end{tabular}

As seen in Table 1, most of the individual studies are articles, and the others are doctoral dissertations, master theses, and conference papers. The included studies conducted in ten countries are Turkey, Malaysia, the United States of America (USA), Iran, Bangladesh, Indonesia, Israel, Taiwan, Thailand, and Greece.

\section{Analysis}

The CMA (Comprehensive Meta-Analysis) program was used to analyze included studies in this study. The proposed process steps for meta-analysis research (Dincer, 2014; Field \& Gillett, 2010) were followed in the present study. The process steps are presented in detail, respectively:

- The subject of the research and the problem situation should be stated based on the literature.

- In light of research criteria, the literature review should be done in the relevant databases.

- Including/excluding criteria should be decided for the meta-analysis.

- The information about the studies included in the research should be transferred to the coding form, and the validity and reliability of this form should be ensured. The heterogeneity of the studies included in the research and the effect model (fixed or random-effects) should be determined.

- The publication bias of the studies included in the research should be determined and visualized with a funnel plot.

- Publication bias should be tested with confidence tests (Begg and Mazumdar, Rosenthal's Safe N Test, etc.).

- Confidence intervals and effect sizes should be visualized by creating a forest graph of the effect coefficients obtained in the research. 
- Whether a moderator analysis can be done should be checked, and subgroup analysis should be made.

- The mentioned procedures should be reported, interpreted, and discussed with the literature and the meta-analysis findings.

In meta-analysis studies, the relationship (correlation, regression, etc.) values obtained in previous studies are converted to Fisher $Z$ values, and analyzes are performed with this value. Then, the obtained results are converted into Pearson product-moment correlation coefficient $(r)$, and this coefficient is interpreted as effect size (Borenstein, Hedges, Higgins, \& Rothstein, 2013; Sen \& Yildirim, 2020). Accordingly, the relationship gets stronger as the correlation coefficient approaches 1 (one) and decreases as the correlation coefficient approaches 0 (zero) (Dincer, 2014). To determine the model to be used in the meta-analysis, the population and sample sizes of the studies are examined. If the study population sizes are the same size, the fixed-effect model is used, and if they are different, the random-effects model is used. According to another assumption, the fixed effects model assumes that the samples in the studies included in the meta-analysis come from the same population. This is almost impossible in educational studies (Bakioglu \& Ozcan, 2016). For this, the heterogeneity test is checked. Suppose the $p$-value is less than .05 due to the heterogeneity test. In that case, there is a significant difference between the studies, and the study is heterogeneous, so a random-effects model should be used. Although the p-value is used in statistical results, the $\mathrm{Q}$ value is usually looked at in meta-analyses as it gives more evident results than the p-value (Dincer, 2014). The use of random effect models for effect size analysis in meta-analysis studies in the field of social sciences was recommended (Sen \& Yildirim, 2020). In addition, according to the $Q$ and $I^{2}$ values obtained in the heterogeneity test, it was confirmed that the effect size was heterogeneous. Therefore, this study used the random-effects model as the analysis model.

Failure to reach every study in the field within the scope of the research may cause publication bias. Publication bias is defined as the reflection of possible biases of published studies into meta-analysis (Bakioglu \& Goktas, 2018). Due to the unpublished work, the language of the work, or the citations it receives, it may not be possible to reach all the resources in the field. Publication bias is the consideration of published studies that often contain significant findings. Language bias is the type that results from only dealing with publications in a particular language. Attribution bias is when other studies refer to only studies that contain significant and positive findings. In the study, the results of the funnel scatterplot, Begg and Mazumdar Rank Correlations method, Rosenthal's Safe N Test, and Duval and Tweedie's trimming and filling test were examined to identify the publication bias problem and provide a solution to it. Although it is impossible to eliminate publication bias, it is essential to reveal that publication bias is at a level that does not affect the study results before starting the meta-analysis.

The forest plot was used to determine the effect sizes and confidence intervals of the studies included in the analysis, and obtained values were visualized and presented. The forest plot shows the effect sizes and confidence intervals of the studies included in the calculation (Lewis \& Clarke, 2001). In the forest plot, each square-shaped image shows the effect size of the corresponding study. The lines extending from both sides of these squares represent the 95\% confidence interval for the predictions. The area of individual squares, on the other hand, indicates the effect size (weight) of the study in the meta-analysis (Bakioglu \& Goktas, 2018). The size of the squares is also linearly related to the sample size, as the weight of the study increases with the sample size and precision. The diamond shape at the bottom of the 
individual squares represents the overall effect size of the meta-analysis and the confidence interval of this effect size (Dincer, 2014). The diamond shape at the bottom of the individual squares represents the overall effect size of the meta-analysis and the confidence interval of this effect size (Dincer, 2014). It is aimed to explain the heterogeneity of results in studies with analog ANOVA (Cooper, Hedges, \& Valentine, 2019).

\section{Results}

First, possible publication bias was examined in the study. Then, descriptive statistics about the studies are reported. The heterogeneity of the effect sizes was tested $\left(Q\right.$ and $\left.I^{2}\right)$. Details of the meta-analyses are written according to the random-effects model. Then, subgroup analyses (ANOVA) were performed to explain the heterogeneity.

\section{Assessment of publication bias}

In meta-analysis studies, one of the parameters to be considered regarding the reliability of the research is publication bias. Interpretation of the funnel plot is a crucial way to control publication bias. This plot may show whether the individual studies that make up the sample cause publication bias. Figure 1 shows the funnel plot of the including studies.

Funnel Plot of Standard Error by Fisher's Z

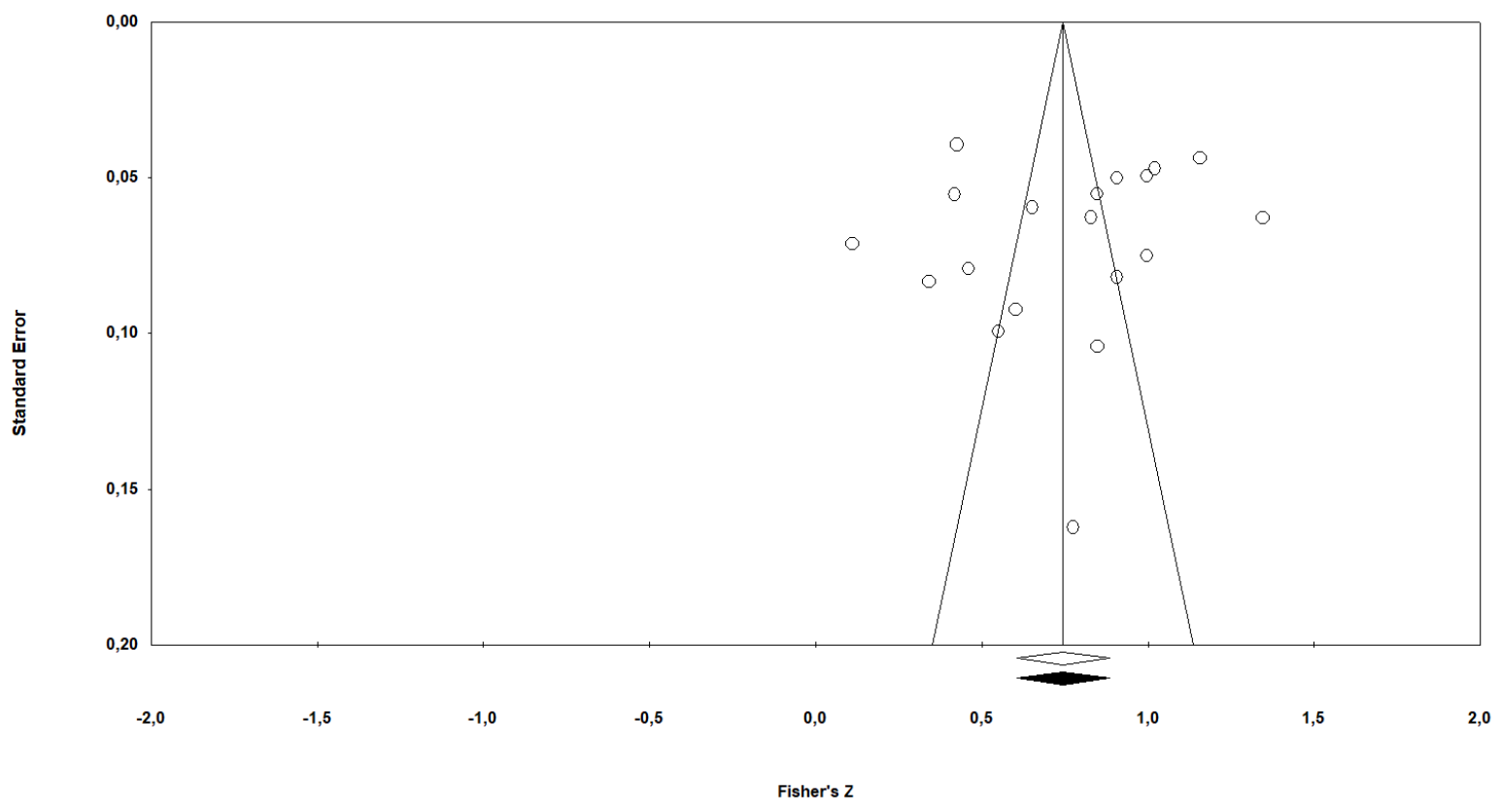

Figure 1. Funnel plot of the study

Figure 1 shows the funnel plot of the results of the included studies. The blank circles $(n=19)$ in the graph represent the studies included in the research, and the black dots represent the unpublished studies necessary to eliminate publication bias. The funnel plot in Figure 1 has no black dots. Therefore, there is no obvious publication bias in the research. In addition, a total of 20 effect sizes included in the study are distributed symmetrically on both sides of the general effect size line. This indicates that there is no explicit publication bias. However, since the interpretation of the funnel plot can be subjective (Borenstein et al., 2013), it is not sufficient on its own to determine publication bias. Besides, the studies spread towards the outside of the funnel on both sides of the funnel graph. This causes the opinion that publication bias should be examined with other analyzes. Table 2 shows the results of 
confidence tests, which were carried out to detect publication bias.

Table 2. Confidence Test Results regarding the Biases of the Studies examined

\begin{tabular}{lll}
\hline Confidence Test & Data of Confidence Test & -0.196 \\
\hline Begg and Mazumdar rank correlation & Kendall's Tau & 1.201 \\
& Z Value for Tau & 0.115 \\
& p-Value (1 Tailed) & 0.230 \\
\hline puval and Tweedie's Trim and Fill & Observed Effect Size Value & 0.744 \\
& Observed Lower Limit & 0.604 \\
& Observed Upper Limit & 0.883 \\
\hline Rosenthal's Fail-Safe N & Z-value for observed studies & 53.039 \\
& The P-value for observed studies & 0.000 \\
& Alpha & 0.050 \\
& Tails & 2.000 \\
& Z for alpha & 1.960 \\
& Number of observed studies & 20 \\
& Number of missing studies that would bring p- & 14626 \\
\hline
\end{tabular}

As seen in Table 2, To detect publication bias, firstly, Begg and Mazumdar Rank Correlations were examined, and Kendall's Tau coefficient obtained was not statistically significant (0.196 and $p=.230$ ). This indicates no publication bias in the study that will affect the research results. There is no publication bias because the Tau value is close to 1, and the twotailed $\mathrm{p}$-value is insignificant $(\mathrm{p}>.05)$. In addition, Rosenthal's Safe N Test gives an idea about the power of the study and the number of studies that should be included in the analysis for the p-value to be greater than the alpha value (Dincer, 2014). The results show that the meta-analysis results are statistically significant $(p=.000)$, and 14626 non-significant individual studies are needed to invalidate them. Since it is not possible to reach so many studies examining the relationship between leadership and learning organizations in educational organizations, it can be said that the study results are safe. Finally, Duval and Tweedie's trim and fill test results, which is a test that predicts what the effect size (adjusted effect size) would be if the funnel diagram regarding publication bias were perfectly symmetrical, were examined. The test result for the random-effects model showed that no study was missing. In the random-effects model, the point estimate and 95\% confidence interval for the combined studies were $0.744(0.604<C I s<0.883)$. To sum up, publication bias is not an essential factor affecting the current study results.

The forest graph created to determine the effect size and confidence intervals of the included studies is presented in Figure 2. 


\begin{tabular}{|c|c|c|c|c|c|c|c|}
\hline \multirow[t]{2}{*}{ Study name } & \multicolumn{7}{|c|}{ Statistics for each study } \\
\hline & $\begin{array}{c}\text { Fisher's } \\
\text { Z }\end{array}$ & $\begin{array}{l}\text { Standard } \\
\text { error }\end{array}$ & Variance & $\begin{array}{c}\text { Lower } \\
\text { limit }\end{array}$ & $\begin{array}{c}\text { Upper } \\
\text { limit }\end{array}$ & Z-Value & p-Value \\
\hline Karabad Köse (2013) & 1,157 & 0,044 & 0,002 & 1,071 & 1,243 & 26,455 & 0,00 \\
\hline Akan \& Sezer (2014) & 0,996 & 0,075 & 0,006 & 0,849 & 1,144 & 13,254 & 0,00 \\
\hline Korkmaz (2006) & 0,829 & 0,063 & 0,004 & 0,706 & 0,952 & 13,214 & 0,00 \\
\hline Aydýn (2012a) & 1,020 & 0,047 & 0,002 & 0,928 & 1,113 & 21,668 & 0,00 \\
\hline Aydýn (2012b) & 0,908 & 0,082 & 0,007 & 0,747 & 1,068 & 11,079 & 0,00 \\
\hline Safia (2020) & 0,996 & 0,050 & 0,002 & 0,899 & 1,093 & 20,123 & 0,00 \\
\hline Ali \& Othman (2007) & 0,775 & 0,162 & 0,026 & 0,457 & 1,093 & 4,779 & 0,00 \\
\hline Hsiao \& Chang (2011) & 0,846 & 0,055 & 0,003 & 0,738 & 0,954 & 15,299 & 0,00 \\
\hline Kurland et al. (2010) & 0,549 & 0,100 & 0,010 & 0,354 & 0,744 & 5,520 & 0,00 \\
\hline Nordin \& Kasbon (2013) & 0,603 & 0,092 & 0,009 & 0,422 & 0,784 & 6,520 & 0,00 \\
\hline Waruwu et al. (2020) & 0,426 & 0,039 & 0,002 & 0,349 & 0,503 & 10,794 & 0,00 \\
\hline Fuziah \& Mohd Izham (2011) & 0,652 & 0,060 & 0,004 & 0,535 & 0,769 & 10,949 & 0,00 \\
\hline Abbasi \& Zamani-Miandashti (2013) & 0,419 & 0,055 & 0,003 & 0,310 & 0,528 & 7,565 & 0,00 \\
\hline Hamzah et al. (2011) & 0,652 & 0,060 & 0,004 & 0,535 & 0,769 & 10,949 & 0,00 \\
\hline Papazoglou \& Koutouzis (2017) & 1,346 & 0,063 & 0,004 & 1,222 & 1,469 & 21,360 & 0,00 \\
\hline Pimonratanakan et al. (2017) & 0,908 & 0,050 & 0,003 & 0,809 & 1,006 & 18,085 & 0,00 \\
\hline Jackson (2020) & 0,460 & 0,079 & 0,006 & 0,304 & 0,615 & 5,799 & 0,00 \\
\hline Keys $(2010)$ & 0,848 & 0,104 & 0,011 & 0,644 & 1,052 & 8,133 & 0,00 \\
\hline Manshadi et al. (2014) & 0,110 & 0,071 & 0,005 & $-0,029$ & 0,250 & 1,550 & 0,12 \\
\hline \multirow[t]{2}{*}{ Uddin et al. (2017) } & 0,342 & 0,083 & 0,007 & 0,178 & 0,505 & 4,100 & 0,00 \\
\hline & 0,744 & 0,071 & 0,005 & 0,604 & 0,883 & 10,456 & 0,00 \\
\hline
\end{tabular}

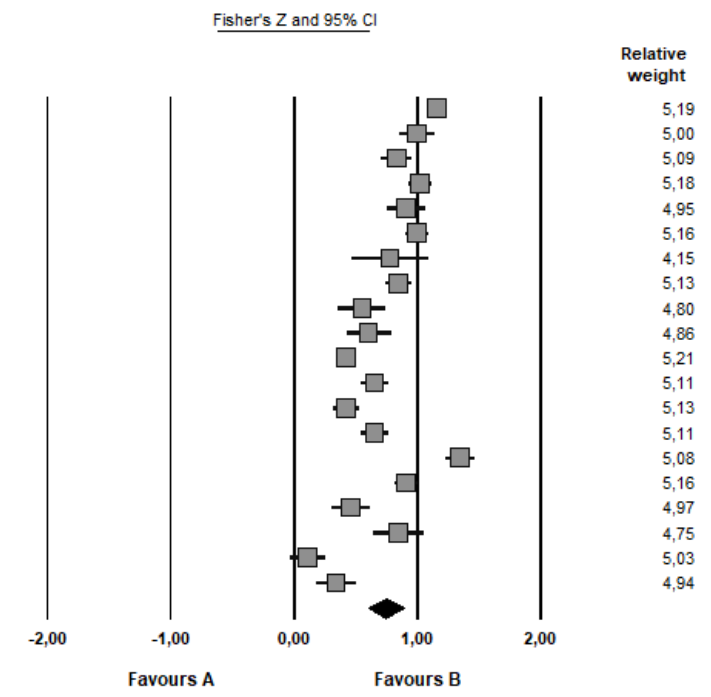

Figure 2. Forest graph of included studies

In Figure 2, the black squares show the effect size of the studies, and the horizontal lines that cut the black squares show the 95\% confidence interval. The Fisher $\mathrm{Z}$ coefficients of the included studies vary between 0.110 and 1.346. In the random-effects model between the school administrators' transformational leadership and teachers' perceptions of learning school, the Fisher $Z$ coefficient was 0.744 and significant $(Z=10.456 ; p=.000)$. This value shows that the relationship in question is at a high level $(r=0.632 ; 0.540<C I s<0.708 ; p=$ $.000)$.

Considering the included studies according to their weights, the confidence interval of Ali and Othman's (2007) study is relatively wider than other studies due to the small number of samples $(n=41)$, and the study weight is lower (weight $=4.15)$. The confidence interval of the Waruwu et al. (2020) study has the narrowest confidence interval and the highest working weight (weight $=5.21)$ due to a large number of samples $(n=645)$. In addition, the diamond shape at the bottom of the graph indicates that the overall effect size of the studies is strong.

\section{Assessment of heterogeneity test}

The findings regarding the heterogeneity test conducted within the scope of the research are shown in Table 3.

Table 3. Results of heterogeneity test

\begin{tabular}{lcccccc}
\cline { 2 - 6 } & \multicolumn{25}{c}{$\mathbf{9 5 \%} \mathbf{C I}$} & & & & \\
\cline { 2 - 6 } Model & $\mathbf{k}$ & $\mathbf{E S}$ & $\begin{array}{c}\text { Lower } \\
\text { Limit }\end{array}$ & $\begin{array}{c}\text { Upper } \\
\text { Limit }\end{array}$ & $\mathbf{Z}$ & $\mathbf{p}$ \\
\hline $\begin{array}{l}\text { Fixed } \\
\text { Effects }\end{array}$ & 20 & 0.776 & 0.749 & 0.803 & 56.568 & .00 \\
\hline $\begin{array}{l}\text { Random } \\
\text { Effect }\end{array}$ & 20 & 0.744 & 0.604 & 0.883 & 10.456 & .00 \\
\hline
\end{tabular}

\begin{tabular}{lccc}
\hline \multicolumn{4}{l}{ Heterogeneity } \\
\hline $\mathbf{Q}$ & $\begin{array}{c}\text { df } \\
(\mathbf{Q})\end{array}$ & $\mathbf{p}$ & $\mathbf{I}^{\mathbf{2}}$ \\
\hline 493.032 & 19 & .00 & 96.146 \\
\hline
\end{tabular}

\begin{tabular}{lc}
\hline Tau $^{2}$ & \\
\hline Tau & se \\
\hline .096 & .037 \\
\hline
\end{tabular}

ES: Effect size; k: number of the study; Q: Cochrane's heterogeneity; df: degree of freedom; se: Standard error

As seen in Table 3, Cochran's $Q$ value $(\mathrm{Q}=493.032 ; \mathrm{df}(\mathrm{Q})=19 ; \mathrm{p}=.00)$ is significant, indicating that the null hypothesis was rejected and the included studies were heterogeneous. As another test of heterogeneity, the $I^{2}$ statistic, which is not affected by the number of studies in the meta-analysis, was used. The result of this test shows a value of $96.146 \%$. This 
indicates that there is a significant rate of variability between studies. Higgins and Thompson (2002) stated that 25\% ( $\left.I^{2}=25\right)$ is low, 50\% $\left(I^{2}=50\right)$ is medium and 75\% $\left(I^{2}=75\right)$ is high heterogeneity in their classification of $I^{2}$ values. Subgroup analysis (moderator) was conducted to find the source of heterogeneity. For this, the country and publication type variables were taken into account. According to the country and publication type of the study, the results of the moderator analysis were calculated according to the Pearson moment correlation coefficient and are shown in Table 4.

Table 4. Results of individual studies by country and type of publication

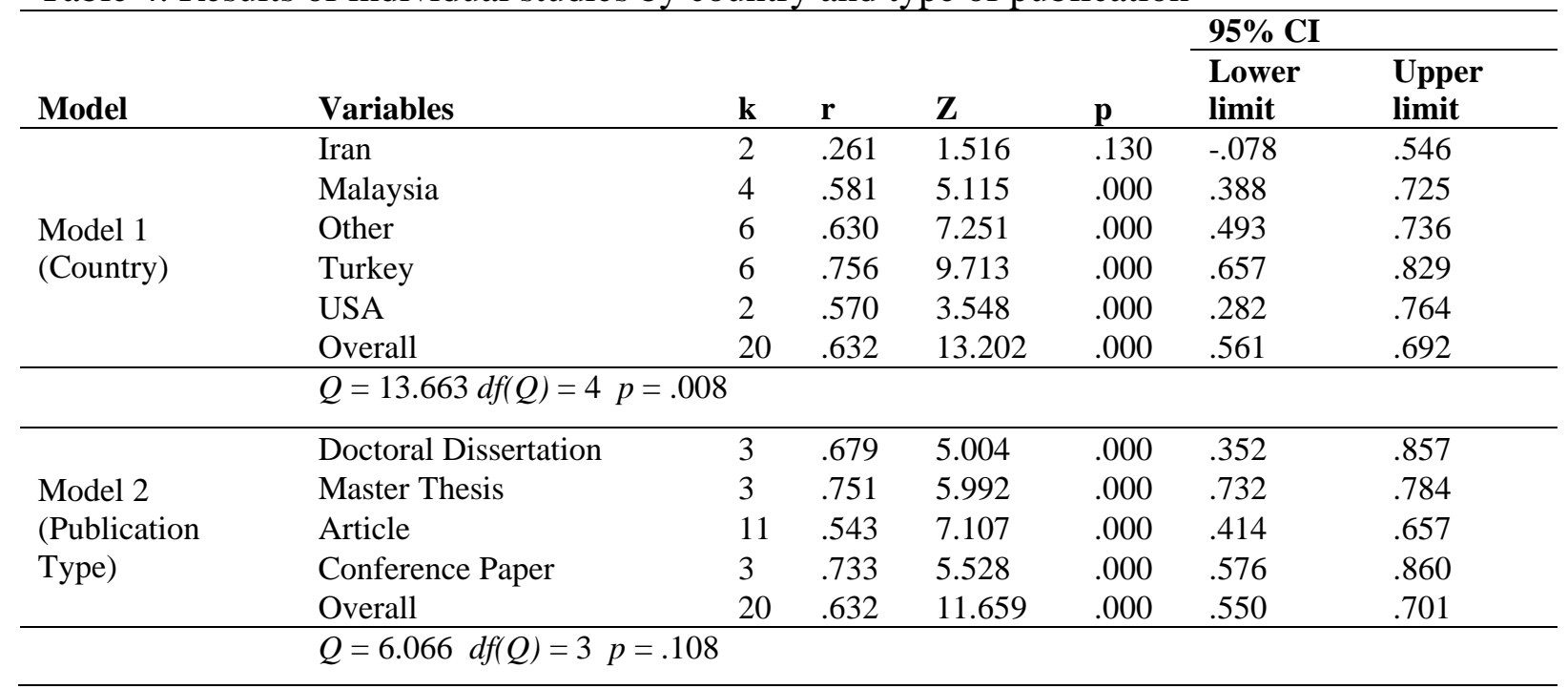

In Table 4, the effect size of each study was disaggregated, and the results of whether the effect size of the relationship between transformational leadership and learning organization differ according to the country where the studies were conducted, and the type of publication of the studies were tested. According to Model 1, the effect size of studies conducted in Iran was $0.267(p>.05)$ in Fisher Z, $0.664(p<.01)$ in Malaysia, $0.986(p<.01)$ in Turkey, 0.647 in the USA $(p<.01)$, while the effect size of studies conducted in other countries was estimated as $0.741(p<.01)$. Except for Iran, the effect sizes of all countries are significant. Thus, the Q value of 13.663 ( $p=.008$ ) shows that effect sizes are significant by country. This result indicates that the country variable may be a source of heterogeneity between studies.

According to Model 2, the effect size of the doctoral dissertation was $0.827(p<.01)$ in the Fisher $Z$, the effect size of the master's theses was $0.976(p<.01)$, and significant $(p<.01)$, the effect size of the articles was $0.609(p<.01)$ and the effect size of the conference papers was estimated as $0.935(p<.01)$. According to the $\mathrm{Q}$ value $(6.066 ; \mathrm{p}=.108)$, the difference between the effect sizes is not significant, and the type of publication variable does not cause heterogeneity between the studies.

\section{Discussion}

Leadership has a powerful influence on learning and development in today's organizations, and transformational leadership is a dominant concept in leadership research. Hence, this study aimed to determine the relationship between the school administrators' transformational leadership and the learning school using the meta-analysis method. To achieve this aim, 19 individual studies were included in the study. The results obtained as a result of the analysis are discussed under this title. 
According to the results, the overall effect size of the relationship between transformational leadership and learning school is positive and strong. Koybasi Semin (2020) also concluded that transformational leadership has a strong effect on organizational learning. Rianto, Jasfar, and Arafah (2021) also stated that transformational leadership and learning organizations are important elements in improving organizational performance. According to Xie's (2020) research results, transformational leadership was a significant and positive relationship with a learning organization.

Leaders develop organizations and their abilities, and leadership gains new meaning in a learning organization (Kofman \& Senge, 1993). The concept of a learning organization will remain a distant vision until leaders develop the leadership that the learning organization needs (Woolner, 1995). For this reason, it should be said that the leadership of the school administrator is crucial in creating a learning school. Learning organization leadership; is a type of leadership that thinks, questions, and takes risks (Kofman \& Senge, 1993). Leaders who will enable transformation are essential factors that reveal the learning organization (Senge, 1990). For this reason, it would be appropriate to say that leadership characteristics are a vital parameter for creating a learning organization. For a learning school, school administrators should create and share knowledge (Omur \& Argon, 2016). The school administrator's support of learning and being a role model by learning with teachers can be seen as behaviors that will help create a learning organization. It will be essential for school administrators to create a learning-oriented vision, share this vision with the other school stakeholders (teachers, students, parents, etc.), and unite them around this vision to create a learning school. It would be appropriate to say that there are some characteristics that the school administrator should have to do these. School administrators should transform the schools they manage into learning organizations by trusting their colleagues, encouraging them, motivating them, giving them responsibility, allowing them to take the initiative, and encouraging them for professional development (Matthews \& Lewis, 2009). School leadership can significantly affect organizational learning processes because the school administrator's interest has a strong and direct relationship with the learning school (Louis et al., 2010); school leadership can significantly affect organizational learning processes (Berson, Da'as, \& Waldman, 2015).

Educational leaders have responsibilities and decision-making roles in educational institutions of all types and levels, and they are responsible for the success and failure of their institutions. Koybasi Semin (2020) concluded that school type is a moderator in the relationship between learning organization and transformational leadership. Educational leaders need to be transformational leaders, especially in creating a learning organization. Kareem (2016) was seen that leadership characteristics play an essential role in creating a learning organization. Because learning organizations guide and facilitate the learning of all their members and constantly transform themselves. While individual learning is encouraged in these organizations, it also focuses on the experiences of the organization regarding the continuous change and adaptation process and learning about the change process itself (Balay et al., 2004). Those who manage these organizations are transformational leaders. It can be assumed that a transformational leader who encourages followers and uses emotional appeal can increase their level of collective effectiveness. This, in turn, encourages employees to take collective action and strive to build shared understanding and practices (Vashdi, Levitats, \& Grimland, 2019).

Different types of leadership may influence the learning organization. Hosseini et al. (2020) concluded that leadership styles are a strong predictor of organizational learning, and research 
on learning organizations focuses on transformational and transactional leadership styles (Bryant, 2003; Xie, 2018), and it was found that there is no significant relationship between transactional leadership and learning schools (Kurland, Peretz, \& Hertz-Lazarowitz, 2010). Unlike transformational leadership, since transactional leadership is a leadership style that focuses on coping with problems with rewards and punishments after issues arise, it is understandable that learning organizations are negatively related or not related to their characteristics based on solving problems when faced with difficulties. Bass and Avolio (2000), transactional leadership focuses on promoting the individual interests of leaders and followers and meeting the parties' contractual obligations by setting goals, monitoring, and controlling results. Transformational leadership and transactional leadership can be thought of as opposites. While transformational leadership can be more effective in creating and sharing knowledge at the individual and group levels, transactional leadership benefits from knowledge at the organizational level, and knowledge production is not in question (Bryant, 2003). For this reason, it can be stated as a type of leadership that is contrary to the nature of learning organizations. The most important thing that needs to be done in transactional leadership to transformational leadership is learning to share the vision (Bass, 1990).

Researchers emphasized the importance of leadership in designing a learning organization (Garvin, 1993; Senge, 1990; Watkins \& Marsick, 1993). Transformational leadership, which defines positive leadership styles, is the leadership style that has dominated the leadership literature since the 1980s (Hoch, Bommer, Dulebohn, \& Wu, 2018). Both the revealed results in the current study and the empirical studies (Korkmaz, 2008; Xie, 2020) confirm these views. Studies indicated that transformational leadership is closely related to and influences organizational learning (García-Morales, Jiménez-Barrionuevo, \& Gutiérrez-Gutiérrez, 2012; Senge, 1990; Swieringa \& Wierdsma, 1992). Rianto et al. (2021) and Wick and Leon (1995) also stated that this leadership style makes everything possible to overcome obstacles that may hinder learning. Transformational leadership is a leadership style that allows organizations to learn through experimentation, discovery, and communication, and it analyzes, changes, and directs organizations, designing them to share and transfer knowledge throughout the organizational learning process (Lei, Slocum, \& Pitts, 1999; Menguc, Auh, \& Shih, 2007; Senge, 1990; Senge, Roberts, Ross, Smith, \& Kleiner, 1994). Therefore, the learning school needs to learn rather than what is known. That is, the learning capacity of the school may be seen as more crucial than what is known. For this reason, school leadership should facilitate learning and take responsibility for it. As Fullan (2001) stated, the school leader should have skills that enable problem-solving processes instead of being an expert who knows everything. It is possible to say that these skills include sharing authority and responsibilities and a shared vision.

\section{Conclusion}

Theoretically, it is generally accepted that school principals are the most important actors in creating a learning school. The study also revealed that one of the most critical leadership styles to create a learning school is transformational leadership. Examined research results also showed that leadership characteristics are significant predictors of learning school. It is stated that the characteristics that reveal transformational leadership are important in creating learning schools (Mulford \& Silins, 2003). Transformational leadership characteristics enable everyone to help each other with high morale and motivation to increase learning and performance. In this sense, it is expected that school principal will use their leadership characteristics to increase the learning capacity of the school. 
To transform schools into learning schools, instead of preserving and maintaining the present, it is necessary to support school stakeholders, motivate them, focus on learning at school and gather all employees around a vision. Leaders always have to focus further without acting according to their hierarchical positions in management to achieve this. For this reason, it is inevitable for school leaders to be transformational leaders. Transformational leaders initiate organizational change with open communication and thought sharing at school. While doing this, they must transfer newly learned information with the knowledge and experiences they have among the employees and create an organizational learning culture.

\section{Limitations}

Current results should be evaluated within the framework of inclusion criteria and the limitations of the research. First of all, since studies published between 2000 and 2020 are included in this research, this study's limitation is that studies outside this range are not included. The criterion that the results of the overall scale of the learning organization were obtained in the study to be included in the study caused that the studies examined the relationships between the transformational leadership characteristic and the dimensions of the learning organization were not included in the study. This situation limits the number of individual studies used in the research and negatively affects the generalizability of the study. In addition, in some studies examining the relationship between leadership characteristics and learning school, using path or regression analysis, the correlation coefficients between variables were not given. And these studies were excluded from the scope of the research. Finally, the current study is limited to studies accessed from online databases. Another limitation of the study is that unpublished studies that could not be accessed from databases could not be included.

\section{Suggestions}

One of the most critical parameters in creating learning schools is the school administrator. The current study results showed that it is essential for school administrators to be transformational leaders for learning schools. For this reason, policymakers and practitioners have essential duties in transforming schools into learning schools.

The most critical characteristics of transformational leaders are being open to change, encouraging change, always being consistent in promoting learning, producing various alternative ways for learning, focusing on the learning process but not the outcome, and planning this process in the long term. Transformational leaders also have characteristics such as creating an open communication climate at school, empathizing, looking from different perspectives, being savvy and stable. Bass $(1985,1998)$ stated that carefully planned training programs could learn transformational leadership behaviors. For this reason, school administrators who want to turn their schools into learning organizations should always be supported by those who produce education policies. Therefore, some training to develop leadership skills should be made compulsory before school administrators are appointed. In this training, some case studies and scenarios should be put into practice to combine theory and practice; their theoretical knowledge and approaches to these events should be examined so that the decision-making and problem-solving skills of the candidates should be developed. In addition, administrators and leadership workshops should be organized at regular intervals. School administrators should be aware of the importance of the leadership characteristics they exhibit for the functioning of schools and should employ leadership practices to improve the school. School administrators should share their vision of the school's functioning with teachers and persuade them to act in this direction. To create a learning school, the 
contribution of any of the school's stakeholders should not be overlooked, and leadership should be exhibited regarding the aims and objectives of the school, including students and their families.

\section{References}

* Studies included in the meta-analysis

Ababneh, S. (2009). Jordan School as a learning organization: Reality and future. Unpublished doctoral thesis, Jordan University, Amman.

*Abbasi, E., \& Zamani-Miandashti, N. (2013). The role of transformational leadership, organizational culture and organizational learning in improving the performance of Iranian agricultural faculties. Higher Education, 66(4), 505-519.

Argyris, C., \& Schön, D. A. (1978). Organizational learning: A theory of action perspective. Reading, MA: Addison-Wesley.

*Akan, D., \& Sezer, Ş. (2014). Relation between the principals' leadership styles and becoming a learning organization level of the schools. Turkish Journal of Educational Studies, 1(2), 126-151.

Alanoglu, M. (2014). The impact of high schools' organizational learning level on school effectiveness and organizational citizenship behaviour. Unpublished master's thesis, Firat University, Elazig.

*Ali, A. K., \& Othman, A. (2007). Headmasters' and headmistresses' roles in facilitating learning organization in selected primary schools in Malaysia: A preliminary study. In the 5th ASEAN Symposium on Educational Management and Leadership (ASEMAL 5) 18-19 August 2007 (pp. 1-12). Kuala Lumpur: Legend Hotel.

*Aydin, M. K. (2012). The relationship between the strategic leadership actions of public and private primary school principals and the dimensions of organizational learning. Unpublished master's thesis, Gazi University, Ankara.

Bakioglu, A., \& Goktas, E. (2018). An educational policy making method: Meta analysis. Journal of Civilization Educational Research, 1(2), 35-54.

Bakioglu, A., \& Ozcan, Ş. (2016). Meta analysis. Ankara: Nobel Publishing.

Balay, R., İpek, C., Demir, K., Titrek, O., Dogan, E., \& Elma, C. (2004). Learning organizations. Ankara: Sandal Publishing.

Bass, B., \& Avolio, B. (2000). Multifactor leadership questionnaire: Technical report. Redwood City, CA: Mind Garden.

Bass, B. M. (1990). From transactional to transformational leadership: Learning to share the vision. Organizational Dynamics, 18(3), 19-31. doi: 10.1016/0090-2616(90)90061-S

Bass, B. M. (1985). Leadership and performance beyond expectations. New York: Free Press.

Bass, B. M. (1998). Transformational leadership: Industrial, military, and educational impact. Mahwah: Lawrence Erlbaum Associates.

Bellibas, M. Ş., Gumus, S., \& Liu, Y. (2020). Does school leadership matter for teachers' classroom practice? The influence of instructional leadership and distributed leadership on instructional quality. School Effectiveness and School Improvement. doi: 10.1080/09243453.2020.1858119

Bellibas, M. Ş., Polatcan, M., \& Kilinc, A. Ç. (2020). Linking instructional leadership to teacher practices: The mediating Effect of shared practice and agency in learning effectiveness. Educational Management Administration \& Leadership, doi: $10.1177 / 1741143220945706$

Bennis, W. G. (1989). Managing the dream: leadership in the 21st century. Journal of Organizational Change Management, 2(1), 6-10. doi: 10.1108/09534818910134040 
Berson, Y., Da'as, R. A., \& Waldman, D. A. (2015). How do leaders and their teams bring about organizational learning and outcomes? Personnel Psychology, 68(1), 79-108.

Bil, E. (2018). The relationship between the concepts of learning organization, organizational trust and job satisfaction of high schools. Unpublished doctoral dissertation, Ankara University, Ankara.

Bryant, S. E. (2003). The role of transformational and transactional leadership in creating, sharing and exploiting organizational knowledge. Journal of Leadership \& Organizational Studies, 9(4), 32-44. doi: 10.1177/107179190300900403

Bryant, A. (2020). Personal mastery-definition and importance to learning. Empowerment motivation self-efficacy self-leadership. Retrieved from https://www.selfleadership.com/blog/personal-mastery-definition-importancelearning\#: :text=\%22Personal\%20Mastery\%20is\%20the\%20process,leadership $\% 20 \mathrm{c}$ an\%20be\%20considered\%20synonymous.

Bolden, R. (2004). What is leadership? Exeter: Centre for Leadership Studies.

Borenstein, M., Hedges, L.V., Higgins, J. P. T., \& Rothstein H. (2013). Meta-analize giriş [Introduction to meta-analysis] (S. Dincer, çev.). Ankara: Anı Publishing.

Burns, J. M. (1978). Leadership. NY: Harper and Row.

Capra, F. (1996). The web of life. London: Harper Collins.

Caldwell, R. (2012). Systems thinking, organizational change and agency: A practice theory critique of Senge's learning organization. Journal of Change Management, 12(2), 145-164. doi: 10.1080/14697017.2011.647923

Celep, C. (2004). Dönüşümsel liderlik [Transformational leadership]. Ankara: Anı Publishing.

ChanLin, L., Hong, J., Horng, J., Chang, S., \& Chu, H. (2006). Factors influencing technology integration in teaching- a Taiwanese perspective. Innovations in Education and Teaching International, 43(1), 57-68.

Chen, Y. C., \& Li, C. I. (2013). Assessing the spiritual leadership effectiveness, the contribution of follower's self-concept and preliminary tests for moderation of culture and managerial position. The Leadership Quarterly, 24, 240-255.

Cohen, L., Manion, L., \& Morrison, K. (2011). Research methods in education (7th. ed.). New York: Routledge.

Clarke, P. (2000). Learning schools, learning systems. New York and London: Bloomsbury Publishing.

Cooper, H., Hedges, L. V., \& Valentine, J. C. (Eds.). (2019). The handbook of research synthesis and meta-analysis. New York: Russell Sage Foundation.

Celik, V. (2012). Educational leadership (6th ed.). Ankara: Pegem Academy.

Denison, D. R., \& Mishra, A. K. (1995). Toward a theory of organizational culture and effectiveness. Organization Science, 6(2), 204-223.

Dexter, S. (2008). Leadership for IT in schools. J. Voogt \& G. Knezek (Eds.). In International handbook of information technology in primary and secondary education (pp. 543551). New York: Springer.

Dincer, S. (2014). Applied meta-analysis in educational sciences. Ankara: Pegem Academy.

Erturk, R., \& Sezgin-Nartgun, Ş. (2019). The relationship between teacher perceptions of distributed leadership and schools as learning organizations. International Journal of Contemporary Educational Research, 6(2), 381-396.

Field, A. P., \& Gillett, R. (2010). How to do a meta-analysis. British Journal of Mathematical and Statistical Psychology, 63(3), 665-694.

Fiol, C. M., \& Lyles, M. A. (1985). Organizational learning. The Academy of Management Review, 10(4), 803-813.

Fullan, M. (2001). Leading in a culture of change. San Francisco: Jossey-Bass. 
*Fuziah, M. Y., \& Mohd Izham, M. H. (2011). The relationship between principal transformational leadership practices and teacher learning organization practices in cluster secondary schools. In 2nd Regional Conference on Educational Leadership and Management 4th to 7th July (pp. 1-10). Kedah: JITRA.

Galimaka, D. B. (2012). Organisational climate, organisational learning, innovation and academic achievement in government aided primary schools in Kampala District. Unpublished doctoral dissertation, Makerere University, Kampala.

Garcia-Morales, V. J., Lopez-Martin, F. J., \& Llamas-Sánchez, R. (2006). Strategic factors and barriers for promoting educational organizational learning. Teaching and Teacher Education, 22(4), 478-502.

García-Morales, V. J., Jiménez-Barrionuevo, M. M., \& Gutiérrez-Gutiérrez, L. (2012). Transformational leadership influence on organizational performance through organizational learning and innovation. Journal of business research, 65(7), 10401050.

Garvin, D.A. (1993). Building a learning organization. Harvard Business Review, 71(4), 7891.

Garvin, D. A., Edmondson, A. C., \& Gino, F. (2008). Is yours a learning organization? Harvard Business Review, 86(3), 109-116.

Goh, S. C. (1998). Toward a learning organization: The strategic building blocks. Advanced Management Journal. 63(2), 15-22.

Goh, S. C., \& Ryan, P. J. (2002). Learning capability, organization factors and firm performance. In The 3rd European Conference on Organizational Knowledge, Learning and Capabilities 5-6 April 2002 (pp. 56-6). Athens: Astir Palace Hotel.

Bahtin, M. M. (2004). Dostoyevski poetikasinin sorunlarl [Problems of Dostoevsky's poethe] (C. Soydemir, Çev.) İstanbul: Metis.

Collinson, V., \& Cook, T. F. (2016). Organizational learning: Improving learning, teaching, and leading in school systems (M. G. Gulcan, Trans.). Ankara: Pegem Academy.

Hallinger, P. (2003). Leading educational change: Reflections on the practice of instructional and transformational leadership. Cambridge Journal of Education, 33(3), 329-52.

Hallinger, P. (2011). Leadership for learning: Lessons from 40 years of empirical research. Journal of Educational Administration, 49(2), 125-142.

Hallinger, P., Piyaman, P., \& Viseshsiri, P. (2017). Assessing the effects of LCL on teacher professional learning in Thailand. Teaching and Teacher Education, 67, 464-476. DOI: 10.1016/j.tate.2017.07.008

*Hamzah, M., Yakop, F. M., Nordin, N. M., \& Rahman, S. (2011). School as learning organisation: The role of principal's transformational leadership in promoting teacher engagement. World Applied Sciences, 14, 58-63.

Higgins, J. P. T., \& Thompson, S. G. (2002). Quantifying heterogeneity in a meta-analysis. Statistics in Medicine, 21, 1539-1558.

Hoch, J. E., Bommer, W. H., Dulebohn, J. H., \& Wu, D. (2018). Do ethical, authentic, and servant leadership explain variance above and beyond transformational leadership? A meta-analysis. Journal of Management, 44(2), 501-529.

Hoe, S. L. (2007). Shared vision: a development tool for organizational learning. Development and Learning in Organizations, 21(4), pp. 1213. https://doi.org/10.1108/14777280710758817.

Hosseini, S. H., Hajipour, E., Kaffashpoor, A., \& Darikandeh, A. (2020). The mediating effect of organizational culture in the relationship of leadership style with organizational learning. Journal of human behavior in the social environment, 30(3), 279-288. 
*Hsiao, H. C., \& Chang, J. C. (2011). The role of organizational learning in transformational leadership and organizational innovation. Asia Pacific Education Review, 12(4), 621631.

Jacobson, S. (2011). Leadership effects on student achievement and sustained school success. The International Journal of Educational Management, 25(1), 33-44.

*Jackson, L. D. (2020). Influence of teachers' psychological safety, principals' transformational leadership, and organizational uncertainty on Schools as learning organizations. Unpublished doctoral dissertation, University of Arkansas at Little Rock, Arkansas.

Jason, M. H. (2000). The role of the principal as transformational leader in a multicultural learning community. High School Journal, 83(3), 1-9.

* Karabag Kose, E. (2013). Primary school teachers' mediating impact of organizational silence and participatory decision making in the relationship between leadership styles and organizational learning. Unpublished doctoral dissertation, Gazi University, Ankara.

Kareem, J. (2016). The influence of leadership in building a learning organization. IUP Journal of Organizational Behavior, 15(1), 7-18.

*Keys, M. R. (2010). The relationship between transformational leadership behaviors of middle school principals, the development of learning communities, and student achievement in rural middle schools in the Mississippi Delta. Unpublished doctoral dissertation, Union University, Jackson, Tennessee.

Kocel, T. (2005). Business Management. Istanbul: Arıkan Publishing.

Kofman, F., \& Senge, P. M. (1993). Communities of commitment: The heart of learning organizations. Organizational Dynamics, 22(2), 5-23.

*Korkmaz, M. (2006). The effect of leadership practices on organizational learning and student outcomes in Turkish high schools. Educational Administration: Theory and Practice, 48(48), 503-529.

Korkmaz, M. (2008). A study of relationship between leadership styles on the characterictics of learning organizations in Turkish public schools. Educational Management in Theory and Practice, 53(53), 75-98.

Koybasi Semin, F. (2020). The relationship between transformational leadership and organizational learning in educational organizations: A meta-analysis study. Hacettepe University Journal of Education. Advance online publication. doi: 10.16986/HUJE.2020064441

Kruse, K. (2013). What is leadership? Forbes. Retireved from http://www.forbes.com/sites/kevinkruse/2013/04/09/what-is-leadership.

*Kurland, H., Peretz, H., \& Hertz-Lazarowitz, R. (2010). Leadership style and organizational learning: The mediate effect of school vision. Journal of Educational Administration, 48(1), 7-30.

Kursunoglu, A., \& Tanriogen, A. (2009). The relationship between teachers' perceptions towards instructional leadership behaviors of their principals and teachers' attitudes towards change. Procedia Social and Behavioral Sciences, 1(1), 252-258.

Lei, D., Slocum, J. W., \& Pitts, R. A. (1999). Designing organizations for competitive advantage: the power of unlearning and learning. Organizational Dynamics, 27(3), 2438 .

Leithwood, K. (1994). Leadership for school restructuring. Educational Administration Quarterly, 30(4), 498-518.

Leithwood, K., \& Jantzi, D. (2006). Transformational school leadership for large scale reform: effects on students, teachers, and their classroom practices. School Effectiveness and School Improvement, 17, 201-227. 
Leithwood, K., \& Sleegers, P. (2006) Transformational school leadership: Introduction. School Effectiveness and School Improvement, 17(2), 143-144. DOI: 10.1080/09243450600565688

Leithwood, K., Sun, J., \& Pollock, K. (Eds.). (2017). How school leaders contribute to student success: The four paths framework (Vol. 23). Springer.

Leithwood, K. (2021). A review of evidence about equitable school leadership. Education Sciences, 11(8), 377. https://doi.org/10.3390/ educsci11080377.

Leithwood, K., Sun, J., \& Schumacker, R. (2020). How school leadership influences student learning: A test of "The four paths model". Educational Administration Quarterly, 56(4), 570-599.

Lewis, S., \& Clarke, M. (2001). Forest plots: Trying to see the wood and the trees. British Medical Journal, 322, 1479-1480.

Lipshitz, R., Popper, M., \& Friedman, V. J. (2002). A multifacet model of organizational learning. The journal of applied behavioral science, 38(1), 78-98.

Louis, K. S., Dretzke, B., \& Wahlstrom, K. (2010). Instructional leadership, shared leadership and student learning: An exploration of the role of the principal. School Effectiveness and School Improvement, 21(3), 315-336.

Lunenburg, F. C., \& Ornstein, A. C. (2013). Educational administration: Concepts and practices (6th ed.). London: Sage.

Malhotra, Y. (1996) Organizational learning and learning organizations: An overview. http://www.brint.com/papers/orglrng.htm

*Manshadi, M. D., Ebrahimi, F. P., \& Abdi, H. M. (2014). A study of the relationship between transformational leadership and organizational learning. European Journal of Experimental Biology, 4(1), 12-20.

Marsick, V. J., \& Watkins, K. E. (1997). Lessons from informal and incidental learning. Management learning: Integrating perspectives in theory and practice, 295311.

Matthews, P., \& Lewis, P. (2009). How do school leaders successfully lead learning?. School leaders report. London: National College for School Leadership.

Menguc, B., Auh, S., \& Shih, E. (2007). Transformational leadership and market orientation: Implications for the implementation of competitive strategies and business unit performance. Journal of business research, 60(4), 314-321.

Middlewood, D. P. R., \& Beer, J. (2005). Creating learning school. London: Paul Chapman Publish.

Mulford, B., \& Silins, H. (2003). Leadership for organisational learning and improved student outcomes-What do we know?. Cambridge Journal of Education, 33(2), 175-195.

*Nordin, N., \& Kasbon, H. (2013). A study on leadership behaviour and organizational learning in higher learning institutions. GSE e-journal of education, 1, 125-134.

OECD (2016). What makes a school a learning organisation? A guide for policy makers, school leaders and teachers. OECD-UNICEF Report.

Omur, Y. E., \& Argon, T. (2016). Teacher opinions on the innovation management skills of school administrators and organizational learning mechanisms. Eurasian Journal of Educational Research, 66, 243-262. DOI: 10.14689/ejer.2016.66.14

*Papazoglou, A., \& Koutouzis, M. (2017). Leadership for transforming Greek schools into learning organizations. In 26th ENIRDELM Conference 14-17 September 2017 (pp.21-35). Krakow: Jagiellonian University.

Pedler, M., Burgoyn, J., \& Boydell, T. (1991). The learning company a strategy for sustainable development (1st.ed.). London: McGraw-Hill Book Company.

*Pimonratanakan, S., Intawee, T., Krajangsaeng, K., \& Pooripakdee, S. (2017). Transformational leadership climate through learning organization toward the 
organizational development. Journal of Administrative and Business Studies, 3(6), 284-291.

Popper, M., \& Lipshitz, R. (2000). Installing mechanisms and instilling values: the role of leaders in organizational learning. The Learning Organization, 7(3), 135-145.

Rashid, R. A., \& Mansor, M. (2018). The influence of organizational learning on teacher leadership. International Journal of Academic Research in Business and Social Sciences, 8(4), 1254-1267.

Rianto, M. R., Jasfar, F., \& Arafah, W. (2021). Mediating effect of organization learning on the relationship between strategic change, knowledge management and transformational leadership: Case of Indonesian Islamic Banks. Journal of Economic Development, Environment and People, 10(3), 26-49.

Rubin, R. S., Munz, D. C., \& Brommer, W. H. (2005). Leading from within: the effects of emotion recognition and personality on transformational leadership behavior. Academy of Management Journal, 48(5), 845-858.

Ustun, U. (2012). To what extent is problem-based learning effective as compared to traditional teaching in science education? A meta-analysis study. Unpublished doctoral dissertation, METU, Ankara.

*Safia, M. (2020). The relationship between the transformational leadership roles, the level of secondary schools as learning organization and teachers' satisfaction from the perspective of teachers. Unpublished master's thesis, Atatürk University, Erzurum.

Senge, P. M. (1990). The discipline. London: Century Business.

Senge, P. M. (2011). Beşinci disiplin [The fifth discipline]. Istanbul: Yapı Kredi.

Senge, P. M. (2014). The fifth discipline fieldbook: Strategies and tools for building a learning organization. Redfern, New South Wales: Currency.

Senge, P.M., Cambron-McCabe, N., Lucas, T., Smith, B., Dutton, J.,

$\&$ Klein, A. (2012). Schools that learn (updated and revised): A fifth discipline fieldbook for educators, parents, and everyone who cares about education. New York, NY: Doubleday.

Senge, P., Roberts, C., Ross, R.B., Smith, B. J., \& Kleiner, A. (1994). The fifth discipline fieldbook. New York: Doubleday.

Sergiovanni, T. J. (2001). The principalship: A reflective practice. San Antonio, TX: Trinity Press.

Singh, B. S. (2018). How school leaders contribute to student success: the four paths framework, School Leadership \& Management, doi: 10.1080/13632434.2018.1523143

Srimulyani, V. A., \& Hutajulu, K. T. (2013). The impact of servant leadership on organizational learning and teacher performance: A study on high school and vocational school teachers in Madiun City. Indonesian Journal of Management and Business, 1(1), 42-53.

Stata, R. (1989). Organizational learning-the key to management innovation. Sloan. Management Review, 30 (3), 63-74.

Susan, B., \& Whiteley, P. (2007). Kusursuz liderlik [Impeccable leadership]. İstanbul: Acar Publishing.

Swieringa, J., \& Wierdsma, A. F. (1992). Becoming a learning organization: Beyond the learning curve (Vol. 62753). Boston, Massachusetts: Addison-Wesley Longman Limited.

Sen, S. (2019). SPSS ile meta-analiz nasıl yapılır? [How to do meta-analysis with SPSS?] Harran Education Journal, 1(2), 1-49. doi: 110.22596/2019.0401.21.49

Sen, S., \& Yildirim, İ. (2020). Meta-analysis applications with CMA. Ankara: Nobel Publishing.

Toremen, F. (2001). Learning school. Ankara: Nobel Publishing. 
Turan, S. (2020). What is leadership? In K. Y1lmaz (Ed.), Leadership theory-researchpractice (pp. 1-5). Ankara: Pegem Academy.

*Uddin, M. A., Fan, L., \& Das, A. K. (2017). A study of the impact of transformational leadership, organizational learning, and knowledge management on organizational innovation. Management Dynamics, 16(2), 42-54.

Vashdi, D. R., Levitats, Z. S., \& Grimland, S. (2019). Which transformational leadership behaviors relate to organizational learning processes? The Learning Organization, 26(2), 176-189.

*Waruwu, H., Asbari, M., Purwanto, A., Nugroho, Y. A., Fikri, M. A. A., Fauji, A., ... \& Dewi, W. R. (2020). The role of transformational leadership, organizational learning and structure on innovation capacity: Evidence from Indonesia private schools. EduPsyCouns: Journal of Education, Psychology and Counseling, 2(1), 378397.

Watkins, K. E., \& Marsick, V. J. (1993). Sculpting the learning organization: Lessons in the art and science of systemic change. San Francisco, CA: Jossey-Bass.

Wick, C. W., \& Leon, L. S. (1995). From ideas to action: creating a learning organization. Human Resource Management, 34(2), 299-311.

Woolner, P. (1995). A development model of the learning organization. Toronto: Woolner Associates.

Xie, L. (2018). Leadership and organizational learning culture: a systematic literature review. European Journal of Training and Development. doi:10.1108/ejtd-06-2018-0056

Xie, L. (2020). The impact of servant leadership and transformational leadership on learning organization: A comparative analysis. Leadership \& Organization Development Journal, 41(2), 220-236.

Yukl, G. (2010). Leadership in organization. New Jersey: Pearson. 


\begin{tabular}{|c|c|c|c|c|c|c|c|c|c|c|c|c|}
\hline Author(s) & Year & Learning Organization Scale & Leadership Scale & Study Type & Country & $\begin{array}{l}\text { Sample } \\
\text { Size }\end{array}$ & $\begin{array}{l}\text { Analysis } \\
\text { Type }\end{array}$ & $\mathbf{r}$ & $\mathbf{p}$ & $\mathbf{t}$ & sd & $\mathbf{R}^{2}$ \\
\hline Karabağ Köse & 2013 & Watkins \& Marsick (1997) & Bass ve Avolio (1995) & $\begin{array}{l}\text { Doctoral } \\
\text { Dissertation }\end{array}$ & Turkey & 526 & Corr & .82 & $\mathrm{p}<.01$ & & & \\
\hline Akan \& Sezer & 2014 & Turkoğlu (2002) & Bass \& Avolio (1990) & Article & Turkey & 180 & Corr & .76 & & & & \\
\hline Korkmaz & 2006 & Silins, Mulford, \& Zarins (1999) & $\begin{array}{l}\text { Silins, Mulford,\& Zarins } \\
\text { (1999) }\end{array}$ & Article & Turkey & 257 & Corr & .68 & $\mathrm{p}<.01$ & & & \\
\hline Aydın & $2012 \mathrm{a}$ & Watkins \& Marsick (1997) & Pisapia (2009) & Master Thesis & Turkey & 454 & Corr & .77 & $\mathrm{p}<.01$ & & & \\
\hline Aydın & $2012 b$ & Watkins \& Marsick (1997) & Pisapia (2009) & Master Thesis & Turkey & 152 & Corr & .72 & $\mathrm{p}<.01$ & & & \\
\hline Safia & 2020 & Uğurlu, Doğan, \& Yiğit (2014) & Toksöz (2010) & Master Thesis & Turkey & 411 & Corr & .76 & $\mathrm{p}<.01$ & & & \\
\hline Ali \& Othman & 2007 & Silins, Zarins, \& Mulford (2002) & $\begin{array}{l}\text { Silins, Zarins, \& Mulford } \\
(2002)\end{array}$ & Presentation & Malaysia & 41 & Corr & .65 & $\mathrm{p}<.01$ & & & \\
\hline Hsiao \& Chang & 2011 & $\begin{array}{l}\text { Kale, Singh, \& Perlmutter } \\
(2000) ; \\
\text { Edmondson } \\
\text { Garci'a-Morales et al. (2006) } \\
\end{array}$ & Bass and Avolio (2006) & Article & Taiwan & 330 & Corr & .689 & $\mathrm{p}<.01$ & & & \\
\hline $\begin{array}{l}\text { Kurland, Perez, \& } \\
\text { Lazarowitz }\end{array}$ & 2010 & $\begin{array}{l}\begin{array}{l}\text { Kurland } \\
(2006)\end{array}\end{array}$ & Bass and Avolio & Article & Israel & 104 & Corr & .5 & $\mathrm{p}<.01$ & & & \\
\hline Nordin \& Kasbon & 2013 & Gomez et al. (2005) & Bass and Avolio & Article & Malaysia & 120 & Corr & .539 & $\mathrm{p}<.01$ & & & \\
\hline Waruwu et al. & 2020 & $\begin{array}{l}\text { Jiménez-Jiménez \& Sanz-Valle } \\
(2011)\end{array}$ & Bass \&Avolio (2000) & Article & Indonesia & 645 & Reg & .38 & & 11.132 & 0,022 & \\
\hline Fuziah \& Mohd Izham & 2011 & Senge (2006) & $\begin{array}{l}\begin{array}{l}\text { Slocum } \\
(2007)\end{array}\end{array}$ & Presentation & Malaysia & 285 & Corr & .573 & $\mathrm{p}<.01$ & & & \\
\hline Abbasi \& Zamani-Miandashti & 2013 & Abbasi \& Zamani-Miandashti & Bass and Avolio & Article & İ̀n & 329 & Tekli Reg & .76 & & 7.132 & & \\
\hline $\begin{array}{l}\text { Hamzah, Yakop, Nordin, \& } \\
\text { Rahman }\end{array}$ & 2011 & Senge (2006) & $\begin{array}{|ll|}\begin{array}{l}\text { Slocum \& } \\
(2007)\end{array} & \text { Hellriegel } \\
\end{array}$ & Article & Malaysia & 285 & Corr & .573 & $\mathrm{p}<.01$ & & & \\
\hline Papazoglou \& Koutouzis & 2017 & Watkins \& Marsick (1997) & Bass and Avolio & Presentation & Yunanistan & 255 & Tekli Reg & .873 & $\mathrm{p}<.01$ & & & .761 \\
\hline $\begin{array}{l}\text { Pimonratanakan, Intawee, } \\
\text { Krajangsaeng, \& Pooripakdee }\end{array}$ & 2017 & $\begin{array}{l}\text { Pimonratanakan, Intawee, } \\
\text { Krajangsaeng, \& Pooripakdee }\end{array}$ & $\begin{array}{l}\text { Pimonratanakan, } \\
\text { Intawee, Krajangsaeng, } \\
\text { \& Pooripakdee }\end{array}$ & Article & Thailand & 400 & Corr & .72 & $\mathrm{p}<.01$ & & & \\
\hline Jackson & 2020 & Watkins \& Marsick (1997) & Garvin et al. (2008) & \begin{tabular}{|l|} 
Doctoral \\
Dissertation \\
\end{tabular} & USA & 162 & Corr & .43 & $\mathrm{p}<.01$ & & & \\
\hline Keys & 2010 & Hord, 1997 & \begin{tabular}{lll|}
$\begin{array}{l}\text { Leithwood } \\
\text { (1997) }\end{array}$ & Jantzi, \\
\end{tabular} & $\begin{array}{l}\text { Doctoral } \\
\text { Dissertation }\end{array}$ & USA & 95 & Corr & .69 & $\mathrm{p}<.01$ & & & \\
\hline Manshadi, Ebrahimi, \& Abdi & 2014 & Mirkamali & Bass and Avolio & Article & Iranian & 200 & Corr & .11 & $\mathrm{p}<.01$ & & & \\
\hline Uddin, Khan, \& Ali & 2017 & Lopez, Peon, \& Ordas (2004) & Bass and Avolio & Article & Bangladesh & 147 & Corr & .329 & $\mathrm{p}<.01$ & & & \\
\hline
\end{tabular}

r: correlation coefficient; sd: standard deviation; Corr: correlation; Reg: regression 